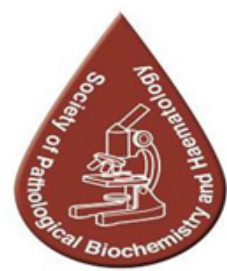

WWW.JBAAR.ORG

\title{
Effect of starvation and drought on the activity of the freshwater crayfish, Procambarus clarkii
}

\author{
Gamalat Y. Osman, Mansour A. Galal, Sherin K. Sheir* and Mona M. Soliman \\ Department of Zoology, Faculty of Science, Menoufia University, Shebin El-kom, Egypt. \\ *Corresponding author: E-mail: sherin.sheir@yahoo.com
}

\begin{abstract}
This study was designed to investigate the effect of starvation and drought on the adult Procumbarus clarkii. Samples were captured from the River Nile, Dakahleyia province, Egypt. Measurements were the animal weight and length and survival rate. The experiment was divided into four groups, control with food and water, starved with water only, drought with food only and starved - drought without any food or water groups. Crayfishes showed great tolerance for 14 weeks $(P<0.05)$. The body weight of the crayfish was more affected than the body and carapace lengths due to the loss of its chelae during starvation. In the starved groups, survival rate of the crayfish declined because its aggressive behavior such as killing each others (66.6\%). Crayfishes could not tolerate drought for a long time ( 5 days). The body weight, length, and the carapace length were minimally influenced during drought, while the survival rate was dramatically affected within few days. The combined effect of both stressors affected the animal survival more drastically within four days (100, 50 and $0 \%$ ). It can be concluded that starvation and drought caused serious changes in P. clarkii behavior,
\end{abstract}

biometry and survival rate, which determine the ability of crayfish to adapt to one or more of the environmental changes.

Keyword: Crayfish, Drought, Starvation, Survival rate

\section{Introduction}

P. clarkii had been introduced into many countries all over the world due to its highly tolerance to the unfavorable conditions such as poor water quality, temperature fluctuations, low oxygen concentrations and desiccation beside its extraordinary production rate in farming (Huner and Lindqvist, 1995). P. clarkii range in size from $8 \mathrm{~cm}$ to $13 \mathrm{~cm}$ in length, hard outer skeleton or carapace, which protected the body and made it rigid, the abdomen had wedge-shaped stripe. Elendt (1989) found that, Daphnia magna could survive under starvation condition dependent on the amount of energy reserved and their subsequent allocation to maintenance, growth, and/or reproduction. Dickson and Giesy (1982) studied the effect of starvation on $P$. clarkii. They indicated that after 30 days of starvation, the dorsal muscle of the tail of starved group contain more ATP and adenylate than the control group. They 
explained that increasing the condition of starvation associated with increased motor activity that may cause greater phosphoadenylate concentration. In addition, during starvation period, crayfish metabolize lipids, proteins, and carbohydrates from various organs in the body to meet their energy demands. The bathypelagic mysid Gnathophausia ingens can survive 19 weeks of starvation (Hiller-Adams and Childress, 1983).

Dall (1974) reported that the rock lobsters, Panulirus longipes survived more than 3 months of starvation in the laboratory. During dry season, crayfish hide in burrows, become inactive and its feeding and growth were greatly reduced (Rhoads, 1976). Hydrological conditions caused crayfish avoid disperse long distances to avoid long period of drought by hiding in burrow in local substratum during the dry downs (Kushlan and Kushlan, 1979). Extreme drought can cause mortality effects on animals like fishes due to decrease oxygen concentrations, high temperatures and other factors (Brochet, 1977 and Brooker et al., 1977). Therefore, the purpose of the present work was to study the effect of starvation, drought alone or in combination on the biometry and activity of the freshwater crayfish, $P$. clarkii

\section{Materials and Methods}

\subsection{Animals collection}

Samples of $P$. clarkii was used in this study were captured from the River Nile at EL-Mashaia region, EL Mansoura, Dakahleyia province, Egypt. Samples were collected from the middle of the River Nile by nets in an area of about $4 \mathrm{~km}$ in length and ranged from 150 to 200 $\mathrm{m}$ in width. Adult males and females of nearly the same size, complete organs and highly active were chosen. Animals were transported to the laboratory and were put in suitable glass aquaria with $50 \mathrm{~cm}$ height, 40 com width and $60 \mathrm{~cm}$ length and covered with wire cover.

Animals were fed regularly on different kinds of agricultural plants as fresh leaves of lettuce, potato tubers, corn and beans. The physiochemical parameters of the water were measured. Temperature ranged from 25-30 ${ }^{\circ} \mathrm{C}$; dissolved oxygen from 4-7 $\mathrm{mg} / \mathrm{l}$; consumed oxygen from 2.4-5.5 mg/l; $\mathrm{pH}$ from 7.5-7.8 and ammonia from $0.06-0.3 \mathrm{mg} / 1.100 \%$ water change was done every other day for the corresponding aquaria with semi static method.

\subsection{Experimental design}

The total number of the animals was 72 , with nearly the same size and weight. The experiment divided into four groups, three replicates and 18 animals/group. Each replicate contains six animals (3 males and 3 females). The first group, were considered as control group and supplied with mud (10-20 cm depth), water (10-20 cm depth) and food. The second group, were considered as starved animals supplied with mud (10-20 cm depth) and water (10-20 cm depth) only but without food. The third group, were considered as drought animals and supplied with mud (10-20 cm depth) and food but without water. The fourth group, were considered as starved - drought animals and supplied with dried mud (10-20 cm depth) only and without food or water.

Body weight, length, carapace length and survival rate in the control and experimental groups were measured at the end of every week until 14 weeks.

\subsection{Statistical analysis}

Data were presented as Mean \pm Standard Deviation and analyzed using Minitab software package (version 16 for Windows) for simple regression analysis where $\mathrm{Y}$ is the variable, $\mathrm{X}$ is the time and $\mathrm{R}^{2}$ is the coefficient of determination. Probability values when $P \leq 0.05$ were defined as significant.

\section{Results}

\subsection{Effect of starvation on biometry and survival rate of adult $P$. clarkii \\ a- Effect of starvation on biometry}

From the experimental observations, the animals ate the mud, their excreta, attacked each other, and ate the weak 
animals between them during the period of starvation. The mean body weight of the control group increased from $38.17 \pm 0.52 \mathrm{~g}$ on the $1^{\text {st }}$ week to the $42.6 \pm 0.33 \mathrm{~g}$ on $14^{\text {th }}$ week. While mean of the body weight of starved group decreased from $41.1 \pm 0.71 \mathrm{~g}$ on $1^{\text {st }}$ week to $41.2 \pm$ $0.96 \mathrm{~g}$ on $14^{\text {th }}$ week (Table 1). There was a significant relationship $(P<0.05)$ between the body weight of $P$. clarkii and time in the control where $\mathbf{Y}=1764.37+$ $0.0446 \mathrm{X}$ and $\mathbf{R}^{\mathbf{2}}=95.43 \%$, and of the starved group where $\mathbf{Y}=-3966.96+0.099 X$ and $\mathbf{R}^{2}=82.60 \%$.

The body length of control group increased from 10.43 $\pm 0.08 \mathrm{~cm}$ on the $1^{\text {st }}$ week and the maximum to $10.78 \pm$ $0.03 \mathrm{~cm}$ on $14^{\text {th }}$ week. While the body length of starved group decreased from $10.68 \pm 0.13 \mathrm{~cm}$ on $1^{\text {st }}$ week to $10.66 \pm 0.08 \mathrm{~cm}$ on $14^{\text {th }}$ week (Table 1 ). There was a significant relationship $(P<0.05)$ between the body length of $P$. clarkii and time of the control group where $\mathbf{Y}=117.833+0.00317 \mathrm{X}$ and $\mathbf{R}^{\mathbf{2}}=91.44 \%$, and of the starved group where $\mathbf{Y}=-279.855+0.00718 X$ and $\mathbf{R}^{2}$ $=80.48 \%$.

The carapace length of the control group increased from $5.37 \pm 0.27 \mathrm{~cm}$ on $1^{\text {st }}$ week to $5.58 \pm 0.02 \mathrm{~cm}$ on $14^{\text {th }}$ week. While the carapace length of starved group decreased from $5.42 \pm 0.28 \mathrm{~cm}$ on $1^{\text {st }}$ week to $5.36 \pm$ $0.03 \mathrm{~cm}$ on $14^{\text {th }}$ week (Table 1). There was a significant relationship $(P<0.05)$ between carapace length and time of $P$. clarkii and time of the control group where $\mathbf{Y}$ $=81.1833+0.00214 \mathrm{X}$ and $\mathbf{R}^{2}=82.99 \%$, and of the starved group where $\mathbf{Y}=-123.54+0.00318937 \mathrm{X}$ and $\mathbf{R}^{2}=67.30 \%$.

\section{b- Effect of starvation on survival rate}

In the control group, the survival percentage of $P$ clarkii was $100 \%$ at $1^{\text {st }}$ week and reached the minimum percentage $66.6 \%$ at $14^{\text {th }}$ week. In the starved group, the survival percentage was $100 \%$ at $1^{\text {st }}$ week and minimum percentage was $0 \%$ at $14^{\text {th }}$ week (Table 1). The relationship of survival rate and time was statistically significant $(P<0.001)$ for the control and starved group where $\mathbf{Y}=131.899-0.00323 \quad \mathrm{X}$ and $\mathbf{R}^{\mathbf{2}}=80.3 \%$., and $\mathbf{Y}=396.473-0.0097 \mathrm{X}$ and $\mathbf{R}^{\mathbf{2}}=97.5 \%$ for control and starved groups, respectively.

\subsection{Effect of drought on biometry and survival rate of adult $P$. clarkii}

\section{a- Effect of drought on biometry}

From the experimental observations, the animals stopped feeding and burrowing in the mud during the period of drought. The body weight of the control group increased from $38.14 \pm 0.7 \mathrm{~g}$ on the $1^{\text {st }}$ day to the $38.3 \pm 0.4 \mathrm{~g}$ on $5^{\text {th }}$ day. While the body weight of drought group decreased from $32.27 \pm 0.29 \mathrm{~g}$ on $1^{\text {st }}$ day to $17.7 \pm 0.17 \mathrm{~g}$ on $5^{\text {th }}$ day (Table 2). There was no statistically significant relationship $(P>0.05)$ between the body weight of $P$. clarkii and time of the control group, where $\mathbf{Y}=-322.257+0.00891 \mathrm{X}$ and $\mathbf{R}^{2}=63.51 \%$, and the drought group where $\mathbf{Y}=82620.3-$ $2.04378 X$ and $\mathbf{R}^{2}=90.50 \%$.

The body length of the control group increased from 10.43 $\pm 0.46 \mathrm{~cm}$ on $1^{\text {st }}$ day to $10.47 \pm 0.09 \mathrm{~cm}$ on $5^{\text {th }}$ day. While the body length of the drought group decreased from 10.02 $\pm 0.13 \mathrm{~cm}$ on $1^{\text {st }}$ day to $9.8 \pm 0.03 \mathrm{~cm}$ on $5^{\text {th }}$ day (Table 2 ). There was no statistically significant relationship $(P>0.05)$ between the body length of $P$. clarkii and time of the control group where $\mathbf{Y}=-173.597+0.00455 \mathrm{X}$ and $\mathbf{R}^{\mathbf{2}}=$ $35.14 \%$, and of the drought group where $\mathbf{Y}=1140.45-$ $0.027 \mathrm{X}$ and $\mathbf{R}^{2}=0.00 \%$.

The carapace length of the control animals ranged from $5.37 \pm 0.05 \mathrm{~cm}$ on $1^{\text {st }}$ day to $5.5 \pm 0.02 \mathrm{~cm}$ on $5^{\text {th }}$ day when compared to the drought group (Table 2). The carapace length of the drought animals did not affect so much where it ranged from $4.95 \pm 0.12 \mathrm{~cm}$ on $1^{\text {st }}$ day to $4.60 \pm 0.11 \mathrm{~cm}$ on $5^{\text {th }}$ day. The relationship between the carapace length of $P$. clarkii and the time (days) was not statistically significant $(P>0.05)$ where $\mathbf{Y}=-11.0035+0.00040 \mathrm{X}$ and $1916.24-0.0472 \quad X$ and $\mathbf{R}^{2}=0 \%$ and $35.14 \%$ for the control and drought groups, respectively. 
Table 1. Body length and weight, carapace length and survival rate of control and starved groups

\begin{tabular}{|c|c|c|c|c|c|c|c|c|}
\hline $\begin{array}{l}\text { Investigation } \\
\text { period }\end{array}$ & $\begin{array}{l}\text { body length } \\
(\mathrm{cm}) \text { of } \\
\text { control group }\end{array}$ & $\begin{array}{l}\text { body length } \\
\text { (cm) of starved } \\
\text { group }\end{array}$ & $\begin{array}{c}\text { carapace } \\
\text { length } \\
(\mathrm{cm}) \text { control } \\
\text { group }\end{array}$ & $\begin{array}{c}\text { carapace } \\
\text { length }(\mathrm{cm}) \\
\text { starved group }\end{array}$ & $\begin{array}{l}\text { body weight } \\
\text { (g) control } \\
\text { group }\end{array}$ & $\begin{array}{l}\text { body weight } \\
\text { (g) starved } \\
\text { group }\end{array}$ & $\begin{array}{c}\text { Survival } \\
\text { rate of } \\
\text { control } \\
\text { group } \\
(\%)\end{array}$ & $\begin{array}{c}\text { Survival } \\
\text { rate of } \\
\text { starved } \\
\text { group }(\%)\end{array}$ \\
\hline $1^{\text {st }}$ week & $10.43 \pm 0.08$ & $10.68 \pm 0.13$ & $5.37 \pm 0.27$ & $5.42 \pm 0.28$ & $38.17 \pm 0.52$ & $41.1 \pm 0.71$ & 100 & 100 \\
\hline $2^{\text {nd }}$ week & $10.47 \pm 0.18$ & $10.68 \pm 0.48$ & $5.37 \pm 0.1$ & $5.38 \pm 0.03$ & $38.28 \pm 0.25$ & $39.98 \pm 0.92$ & 100 & 100 \\
\hline $3^{\text {rd }}$ week & $10.5 \pm 0.33$ & $10.70 \pm 0.06$ & $5.34 \pm 0.23$ & $5.38 \pm 0.03$ & $38.55 \pm 0.34$ & $40.02 \pm 0.76$ & 100 & 83.3 \\
\hline $4^{\text {th }}$ week & $10.55 \pm 0.43$ & $10.70 \pm 0.23$ & $5.37 \pm 0.45$ & $5.38 \pm 0.03$ & $39.07 \pm 0.56$ & $41.04 \pm 0.93$ & 83.3 & 83.3 \\
\hline $5^{\text {th }}$ week & $10.68 \pm 0.63$ & $10.71 \pm 0.53$ & $5.48 \pm 0.84$ & $5.39 \pm 0.03$ & $39.64 \pm 0.12$ & $40.86 \pm 0.36$ & 83.3 & 83.3 \\
\hline $6^{\text {th }}$ week & $10.64 \pm 0.45$ & $10.69 \pm 0.09$ & $5.48 \pm 0.28$ & $5.38 \pm 0.03$ & $39.77 \pm 0.33$ & $40.48 \pm 0.35$ & 83.3 & 47.9 \\
\hline $7^{\text {th }}$ week & $10.64 \pm 0.02$ & $10.68 \pm 0.86$ & $5.48 \pm 0.29$ & $5.37 \pm 0.03$ & $39.86 \pm 0.76$ & $41.95 \pm 0.94$ & 83.3 & 66.6 \\
\hline $8^{\text {th }}$ week & $10.66 \pm 0.04$ & $10.68 \pm 0.38$ & $5.48 \pm 0.39$ & $5.38 \pm 0.03$ & $40.12 \pm 0.66$ & $41.95 \pm 0.35$ & 83.3 & 50 \\
\hline $9^{\text {th }}$ week & $10.68 \pm 0.12$ & $10.63 \pm 0.88$ & $5.5 \pm 0.75$ & $5.37 \pm 0.03$ & $41.2 \pm 0.34$ & $41.0 \pm 0.37$ & 83.3 & 50 \\
\hline 10 week & $10.68 \pm 0.03$ & $10.63 \pm 0.09$ & $5.5 \pm 0.02$ & $5.37 \pm 0.03$ & $41.2 \pm 0.35$ & $41.0 \pm 0.45$ & 83.3 & 50 \\
\hline $11^{\text {th }}$ week & $10.68 \pm 0.37$ & $10.63 \pm 0.08$ & $5.5 \pm 0.19$ & $5.37 \pm 0.03$ & $41.26 \pm 0.56$ & $40.99 \pm 0.96$ & 83.3 & 33.3 \\
\hline $12^{\text {th }}$ week & $10.68 \pm 0.09$ & $10.64 \pm 0.11$ & $5.5 \pm 0.08$ & $5.36 \pm 0.03$ & $41.06 \pm 0.46$ & $41.25 \pm 0.66$ & 66.6 & 16.6 \\
\hline $13^{\text {th }}$ week & $10.78 \pm 0.07$ & $10.66 \pm 0.09$ & $5.58 \pm 0.04$ & $5.36 \pm 0.03$ & $42.6 \pm 0.35$ & $41.3 \pm 0.95$ & 66.6 & 16.6 \\
\hline $14^{\text {th }}$ week & $10.78 \pm 0.03$ & $10.66 \pm 0.08$ & $5.58 \pm 0.02$ & $5.36 \pm 0.03$ & $42.6 \pm 0.33$ & $41.2 \pm 0.96$ & 66.6 & 0 \\
\hline
\end{tabular}

Note, $n=6$

Table 2. Body length, weight, carapace length and survival rate of control and drought groups

\begin{tabular}{|c|c|c|c|c|c|c|c|c|}
\hline $\begin{array}{l}\text { Investigation } \\
\text { period }\end{array}$ & $\begin{array}{l}\text { Body length } \\
(\mathrm{cm}) \text { of } \\
\text { control group }\end{array}$ & $\begin{array}{l}\text { Body length } \\
\text { (cm) of } \\
\text { drought group }\end{array}$ & $\begin{array}{l}\text { Carapace } \\
\text { length } \\
\text { (cm) of } \\
\text { control group }\end{array}$ & $\begin{array}{l}\text { Carapace } \\
\text { length }(\mathrm{cm}) \\
\text { of drought } \\
\text { group }\end{array}$ & $\begin{array}{l}\text { Body weight } \\
\text { (g) of control } \\
\text { group }\end{array}$ & $\begin{array}{l}\text { Body weight } \\
\text { (g) of drought } \\
\text { group }\end{array}$ & $\begin{array}{l}\text { Survival } \\
\text { rate of } \\
\text { control } \\
\text { group } \\
(\%)\end{array}$ & $\begin{array}{c}\text { Survival } \\
\text { rate of } \\
\text { Drought } \\
\text { group } \\
(\%)\end{array}$ \\
\hline $1^{\text {st }}$ day & $10.43 \pm 0.46$ & $10.02 \pm 0.13$ & $5.37 \pm 0.05$ & $4.95 \pm 0.12$ & $38.14 \pm 0.7$ & $32.27 \pm 0.29$ & 100 & 100 \\
\hline $3^{\text {rd }}$ day & $10.43 \pm 0.14$ & $10.01 \pm 0.12$ & $5.38 \pm 0.09$ & $4.90 \pm 0.15$ & $38.2 \pm 0.2$ & $26.73 \pm 0.28$ & 100 & 16.6 \\
\hline $5^{\text {th }}$ day & $10.47 \pm 0.09$ & $9.8 \pm 0.03$ & $5.5 \pm 0.02$ & $4.60 \pm 0.11$ & $38.3 \pm 0.4$ & $17.7 \pm 0.17$ & 100 & 0 \\
\hline
\end{tabular}

Note, $n=6$ 


\section{b-Effect of drought on survival rate}

Drought did not change the survival percentage in the control group, while the survival rate of drought animals decreased from $100 \%$ on $1^{\text {st }}$ day to $0 \%$ on $5^{\text {th }}$ day (Table 2). The relationship between survival rate of $P$. clarkii and experimental time was not significant $(P>0.05) \mathbf{Y}=$ $1.54578-1.3513 \mathrm{X}$ and $5917.02-0.1464 \mathrm{X}$ and $\mathbf{R}^{2}=0 \%$ and $84.10 \%$ for the control and drought groups, respectively.

\subsection{Effect of drought - starvation on biometry}

\section{and survival rate of adult $P$. clarkii}

\section{a- Effect of drought - starvation on biometry}

The body weight of the control group recorded $38.14 \pm$ $0.5 \mathrm{~g}$ on $1^{\text {st }}$ day and $38.2 \pm 0.2 \mathrm{~g}$ on $4^{\text {th }}$ day. On the other hand, drought and starved group recorded $40.05 \pm 0.09$ $\mathrm{g}$ on $1^{\text {st }}$ day and $30.13 \pm 0.23 \mathrm{~g}$ on $4^{\text {th }}$ day (Table 3 ). The relationship of the body weight and time was not statistically significant $(P>0.05)$. Where, $\mathbf{Y}=-322.257$ $+0.00891 \mathrm{X}$ and $58539.6-1.4477 \mathrm{X}$ and $\mathbf{R}^{2}=63.51 \%$ and $87.70 \%$ for the control and drought- starved animals, respectively.

The body length of the control animals did not change and the mean was $10.43 \pm 0.12 \mathrm{~cm}$ on $1^{\text {st }}$ day and 10.47 $\pm 0.11 \mathrm{~cm}$ on $4^{\text {th }}$ day of the experiment. However, in the drought - starved animals, the body length decreased slightly from $10.63 \pm 0.15 \mathrm{~cm}^{\text {on }} 1^{\text {st }}$ day to $10.20 \pm 0.08$ $\mathrm{cm}$ on $4^{\text {th }}$ day (Table 3). The relationship was statistically insignificant $(P>0.05)$ between the body length and experimental time of the control and drought -starved groups. The control group was $\mathbf{Y}=-173.597+$ $0.00455 \mathrm{X}$ and $\mathbf{R}^{2}=35.14 \%$, and the drought - starved group was $\mathbf{Y}=-2059+0.0512 \mathrm{X}$ and $\mathbf{R}^{2}=73.78 \%$.

The carapace length did not affect in the control and drought - starved group with values $5.37 \pm 0.06$ and $5.36 \pm$ $0.05 \mathrm{~cm}$ on $4^{\text {th }}$ day, respectively (Table 3 ). The relationship between the carapace length of $P$. clarkii and the experimental time was statistically insignificant $(P>0.05)$. where $\mathbf{Y}=-11.0035+0.000405 \mathrm{X}$ and $-868.264+0.0216 \mathrm{X}$ and $\mathbf{R}^{2}=0 \%$ and $35.14 \%$ for the control and drought starved groups, respectively.

\section{b- Effect of drought - starvation on survival rate}

The drought and starvation affected and changed the survival rate. The maximum survival rate was $100 \%$ animals at $1^{\text {st }}$ day and the minimum percentage of survival rate at $4^{\text {th }}$ day was $0 \%$. Survival rate of the control group did not change during the investigation period and the percentage of survival rate was $100 \%$ (Table 3). The relationship between the survival rate of $P$. clarkii and the experimental time was statistically insignificant was $(P>$ $0.05)$ for the control group $\left(\mathbf{Y}=1.54578-1.351 \mathrm{X}\right.$ and $\mathbf{R}^{\mathbf{2}}=$ $0 \%)$. However, for the drought - starved group, the relation was statistically significant $(P \leq 0.05, \mathbf{Y}=5734.73-0.1418$ $\mathrm{X}$ and $\mathbf{R}^{2}=98.65 \%$ ).

Table 3. Body length, weight, carapace length and survival rate of control and drought - starved groups

\begin{tabular}{|c|c|c|c|c|c|c|c|c|}
\hline $\begin{array}{l}\text { Investigation } \\
\text { period }\end{array}$ & $\begin{array}{l}\text { Body length } \\
(\mathrm{cm}) \text { of } \\
\text { control group }\end{array}$ & $\begin{array}{l}\text { Body length } \\
\text { (cm) of drought } \\
\text { - starved group }\end{array}$ & $\begin{array}{l}\text { Carapace } \\
\text { length } \\
\text { (cm) of } \\
\text { control group }\end{array}$ & $\begin{array}{c}\text { Carapace } \\
\text { length }(\mathrm{cm}) \text { of } \\
\text { drought }- \text { starved } \\
\text { group }\end{array}$ & $\begin{array}{l}\text { Body weight } \\
\text { (g) of control } \\
\text { group }\end{array}$ & $\begin{array}{c}\text { Body weight (g) } \\
\text { of drought - } \\
\text { starved group }\end{array}$ & $\begin{array}{c}\text { Survival } \\
\text { rate of } \\
\text { control } \\
\text { group } \\
(\%)\end{array}$ & $\begin{array}{c}\text { Survival rate } \\
\text { of drought - } \\
\text { starved group } \\
(\%)\end{array}$ \\
\hline $1^{\text {st }}$ day & $10.43 \pm 0.12$ & $10.63 \pm 0.15$ & $5.37 \pm 0.07$ & $5.47 \pm 0.08$ & $38.14 \pm 0.5$ & $40.05 \pm 0.09$ & 100 & 100 \\
\hline $3^{\text {rd }}$ day & $10.43 \pm 0.09$ & $10.72 \pm 0.11$ & $5.37 \pm 0.05$ & $5.47 \pm 0.1$ & $38.2 \pm 0.3$ & $32.12 \pm 0.13$ & 100 & 50 \\
\hline $4^{\text {th }}$ day & $10.47 \pm 0.11$ & $10.20 \pm 0.08$ & $5.37 \pm 0.06$ & $5.36 \pm 0.05$ & $38.2 \pm 0.2$ & $30.13 \pm 0.23$ & 100 & 0 \\
\hline
\end{tabular}

Note, $n=6$ 


\section{Discussion}

In the present work, the 14 weeks of starvation periods decreased the body weight, total body length and carapace length of $P$. clarkii by decreasing it. $P$. clarkii tolerated for a long time without food and the relationship between survival rate and time of this study was statistically significant $(P<0.05)$. When environmental conditions were unfavorable for normal activity, the ability to regulate the mobilization of energy reserves could potentially maximize the survival time of an individual (Storey and Storey, 1990). The effects of starvation on crustacean metabolism were well documented and involve the major physiological systems of the body. $P$.clarkii could remain in the burrows for 4-5 months until water levels rise either through natural rains or artificial flooding in ponds. If there is little or no food available in the burrow, it was hypothesized that the crayfish feed minimally during this time (Jaspers and Avault, 1969). Morsy (2001) proved that, starvation affected $P$. clarkii by decreasing in total body weight to $0.5 \pm 0.28 \mathrm{~g}$. In addition, decrease in total body length reached to $3 \mathrm{~cm}$ and a slightly decrease in carapace and abdominal length and survival rate to $9 \%$ after more than seven weeks of starvation. Dickson and Giesy (1982) proved that Physiologic responses to starvation while in the burrow might be a key factor in determining individual species success. During starvation, crayfish had been reported to metabolize lipids, proteins, and carbohydrates from various organs in the body to meet these energy demands and that can cause depletion of these important biological molecules (Hazlett et al., 1975 and Speck and Urich, 1969). The main nutrient storage sites in crustaceans are hepatopancreas and abdominal muscle that utilized during starvation (Schirf et al., 1987 and Jones and Obst, 2000). Ansell (1973) and Hazlett et al. (1975) indicated that starvation at early stages caused changes in motor activity patterns. Starvation can cause decrease in the whole animal and individual tissue metabolic rates for most species (Marsden et al., 1973 and Newell, 1973). Powell (2000) indicated that all seven of the enzymes measured in both the tail muscle and hepatopancreas of $P$. clarkii had decreased in total activity by $50 \%$ or more compared to fed controls and the loss in enzyme activity was directly related to loss of tissue mass. In the current study, the change in the weight of fed and starved $P$. clarkii could be attributed to the metabolism of stored energy yielding constituents.

The presented study indicated that, drought had side effects on $P$. clarkii life and caused high or complete mortality. Drought affected the river water quality by increasing total dissolved solids and their constituent ions, elevated ammonia and biochemical oxygen demand, and decreased dissolved oxygen and suspended sediments (Anderson and McCall, 1968; Anderson et al. 1972; Stefan and Combs, 1978; Muchmore and Dziegielewski, 1983). Responses to drought were different from species to another. In fish drought had lethal effect due to low oxygen concentrations, high temperatures and other factors Brochet, 1977; Brooker et al., 1977). On the other hand, the response for invertebrates might be diverse, which cause declines and stability of populations of various species (Moth Iversen et al., 1978; Taylor, 1983; Canton, 1984; Cowx et al., 1984; Kownacki, 1985). P. clarkii was able to tolerate dry periods of up to four months (Henttonen and Huner, 1999). During dry season, crayfishes were inactive in burrows by reducing feeding and growth rates (Rhoads, 1976) and affected its ability to reach the hyporheic zone (Dyer et al., 2014).

In conclusion, drought influenced on $P$. clarkii behavior, biometry and survival rate more than starvation. Both 
stressors alone or in combination may affect population diversity of this animal in a given ecosystem.

\section{References}

Anderson, P.W., McCall, J.E. (1968). Effect of drought on stream quality in New Jersey. J Sun Eng Div, Proc Am Soc Civ Eng, 94: 779-88.

Anderson, P.W., Faust, S.D., McCall, J.E. (1972). Impact of drought on New Jersey's water resources. J Irrig Drain Div, Proc Am Soc Civ Eng, 98(IR3): 37585.

Ansell, A.D. (1973). Changes in oxygen consumption, heart rate and ventilation accompanying starvation in the decapoda crustacean Cancer pugarus. Neth J Sea Res, 7: 455-475.

Brochet, P. (1977). The 1976 drought in France: climatological aspects and consequences. Hydrol Sci Bull, 22: 393-411.

Brooker, M.P., Morris, D.L., Hemsworth, R.J. (1977). Mass mortalities of adult salmon, Salmo salar, in the Wye. J App Ecol, 74:409-417.

Canton, S.P., Cline, L.D., Short, R.A., Ward, J.V. (1984). The macro invertebrates and fish of a Colorado stream during a period of fluctuating discharge. Freshw Biol, 14:311-316.

Cowx, I.G., Young, W.O., Hellawell, J.M. (1984). The influence of drought on the fish and invertebrate populations of an upland stream in Wales. Freshw Biol, 14: 165-77.

Dall, W. (1974). Indices of nutritional state in the western rock lobster, Panulirus longipes (Milne Edwards).I. Blood and tissue constituents and water content. J Expermin Mar Biol Ecol, 16: 167-180.

Dickson, G.W., Giesy, J.P. (1982). The effects of starvation on muscle phosphoadenylate concentrations and adenylate energy charge of surface and cave crayfish. Comp Biochem Physiol, 71(A): 357-361.

Dyer, J.J., Worthington, T.A., Brewer, S.K. (2014). Response of crayfish to hyporheic water availability and excess sedimentation. Hydrobiologia, 111.

Elendt, B.P. (1989). Effects of starvation on growth, reproduction, survival and biochemical composition of Daphnia magna. Archiv für Hydrobiologie, 116: 415-433.

Hazlett, B., Rubenstein, D., Rittschoff, D. (1975). Starvation, energy reserves and aggression in the crayfish Orconectes virilis (Hagen, 1870): (Decapoda, Cambaridae). Crustaceana, 28: 11-16.

Henttonen, P., Huner, J.V. (1999). The introduction of alien species of crayfish in Europe:A historical introduction. In: Gherardi, F. and Holdich D.M., (eds). Crayfish in Europe as Alien Species. Crustacean issuses, 11, A.A. Balkema, Rotterdam, Nethrlands, 13-22.

Hiller-Adams, P., Childress, J.J. (1983). Effects of prolonged starvation on oxygen consumption, ammonia excretion, and chemical composition of the bathypelagic mysid Gnathophausia ingens. Mar Biol, 77: 119-127.
Huner, J.V., Lindqvist O.V. (1995). Physiological adaptations of freshwater crayfishes that permit successful aquaculture enterprises. Am Zool, 35: 12-19.

Jaspers, E., Avault, J.W. (1969). Environmental conditions in burrows and ponds of the red swamp crawfish, Procambarus clarkii (Girard), near Baton Rouge, Louisiana. Proc Ann Conf Southeast Assoc Game Fish Commission, 23: 634-648.

Jones, P.L., Obst, J.H. (2000). Effects of starvation and subsequent refeeding on the size and nutrient content of the hepatopancreas of Cherax destructor (Decapoda: Parastacidae). J Crust Biol, 20: 431-441.

Kownacki, A. (1985). Effect of droughts on the macroinvertebrate communities of high mountain streams. Verh Znt Ver Limnol, 22: 2069-2072.

Kushlan, J.A., Kushlan, M.S. (1979). Observations on crayfish in the Everglades Florida, USA. Crustaceana, 5: 115-120.

Marsden, I.D., Newell, R.C., Ahsanullah, M. (1973). The effect of starvation on the metabolism of the shoreb crab, Carcinus maenus. Comp Biochem Physiol, 45(A): 195-213.

Morsy, E.M.M. (2001). Studies on the freshwater crayfish (Crustacean, Decapoda) recently Invading the Egyptian freshwater. $\mathrm{PhD}$ Thesis, Department of Zooology, Faculty of Science, Tanta University, pp.74104.

Moth Iversen, T., Wiberg-Larsen, P., Birkholm Hansen, S., Hansen, F.S. (1978). The effect of partial and total drought on the macroinvertebrate communities of three small Danish streams. Hydrobiology, 60: 23542 .

Muchmore, C.B., Dziegielewski, B. (1983). Impact of drought on quality of potential water supply sources in the Sangamon River basin. J Am Water Resour Assoc, 19: 37-46.

Newell, R.C. (1973). Factors affecting the respiration of intertidal invertebrates. Am Zool, 13: 513528.

Powell, M.L. (2000). The effects of temperature and nutrient level on energy metabolism in two sympatric crayfish species. Dissertation. University of Alabama at Birmingham, Birmingham, Alabama, USA.

Rhoads, P.B. (1976). Aspects of the life cycle and ecology of Procambarus alleni in the Everglades (Crustacea ,Decapoda Astacidae). ASB Bull, 23- 90.

Schirf, V.R., Turner, P., Selby, L., Hannapel, C., LCruz, P.D., Dehn, P.F. (1987). Nutritional status and energy metabolism of crayfish (Procambarus clarkii, Girard) muscle and hepatopancreas. Comp Biochem Physiol, 88A:383-386.

Speck, U., Urich, K. (1969). Consumption of body constituents during starvation in the crayfish, Orconectes Limosus. Zeitschrift fur vergleichende, 63: 410-414.

Stefan, H., Combs, W.S.J. (1978). Dissolved oxygen and water temperature studies in pool No. 2 of the upper Mississippi River. Verh Znt Ver Limnol, 20: 1744-1751. 
Storey, K.B., Storey, J.M. (1990). Metabolic rate depression and biochemical adaptation in an aerobiosis, hibernation and estivation. Quart Rev Biol, 65: 145174.
Taylor, R.C. (1983). Drought induced changes in crayfish populations along a river continuum. Am Midland Naturalist, 110: 286-98. 